\title{
The Effects of Group Musical Activities on Children's Behaviour
}

\author{
Shiela Jay P. Pineda \\ Faculty of University of the Philippines Integrated School \\ Ma. Regidor St., Cor. Quirino Avenue, University of the Philippines, Diliman, Quezon City, \\ Philippines \\ e-mail: shielajaypineda@gmail.com
}

Published online: 30 December 2017

Cite this article (APA): Pineda, S.J.P. (2017). The effects of group musical activities on children's behaviour. Malaysian Music Journal, 6(2), 49-70.

\begin{abstract}
The study sought to examine the effects of group musical activities on children's challenging behaviour. Six Grade Five students participated in this mixed-method case study. Qualitative data were gathered from observations, interviews, and written outputs. The quantitative data used the BarOn Emotional Quotient Inventory: Youth Version (BarOn EQ-i: YV) instrument to measure socio-emotional skills and behaviour levels. The qualitative results suggested that group musical activities such as listening and moving to music, singing, instrument-playing, improvising, and composing positively affected the behaviours of children in terms of (1) being considerate of others' feelings, thoughts, and ideas; (2) doing one's best in a role or task given; (3) focusing; and (4) being creative and confident. Analysis of the t-test of the BarOn EQ-i: $Y V$, pretest and posttest result, with a range from 0.087 to 0.973 at 0.05 significance level, was not significant which was possibly due to the threats to validity such as history and experimental mortality. However, a comparison of the pretest and posttest raw scores of individual students revealed mixed results.
\end{abstract}

Keywords: behaviour, challenging behaviours, children, group musical activities, socioemotional

Several studies have established the relationship of musical engagement and behavioural development. As a shared human activity, music-making affects behaviour through interactions and influences the collective understanding of individuals (Merriam, 1964; Kaplan, 1990; Elliot, 1995; Bowman, 2002; Burnard \& Younker, 2010). More specifically, musical engagement can be used to achieve the following: encourage interaction during problem-solving activities, develop 
decision-making skills and positive attitude such as acceptance, empathy, and cooperation, and provide a means for individuals to express their creativity (Anshel \& Kipper, 1988; Hoffer, 2002; Rief, 2005; Moore, 2002; Kirschner \& Tomasello, 2010; Cohen, Laya, Sangiorgio, \& Iadeluca, 2011; Cross, Laurence, \& Rabinowitch, 2011). In studies among children, music has been connected to their enhanced selfperception, improved social skills and behaviours, positive well-being, and stronger sense of community and ethical perspective (Standley, 1996; Stamou, 2002; Majoribanks \& Mboya, 2004; North, Tarrant, \& Hargreaves, 2004; Schnitzlein, 2006; Hallam, 2010; Allsup \& Westerlund, 2012). In the Philippines, a study on the effects of music on children's character found that music has a significant correlation to the following set of attitudes: focus and concentration; participation and cooperation; and confidence and courage (Schnitzlein, 2006).

Moreover, music has also been used as an intervention to address (1) behavioural concerns in clinical treatments (Aldridge, 1993; Choi, Lee, \& Lee, 2008; Davoli, 2008; Gooding, 2011); and (2) challenging behaviours of students with special needs (Greher, Hillier, \& Poto, 2010; Machalicek, O’Reilly, Beretvas, Sigafoos, \& Lancioni, 2007; Whipple, 2004). In the clinical setting, music as an intervention tool through music therapy has been used in combination with play therapy for children and as group music therapy for adolescent psychotherapy (Aldridge, 1993). In the school setting, music classrooms have shown to be an ideal setting for building socio-emotional skills which are important in stimulating brain development and in reducing at-risk behaviours in school (Jacobi, 2012). National organizations reiterate the importance of conducting early intervention programs especially among children with challenging behaviours (Fox, Dunlap, \& Powell, 2002). This is mainly because interventions applied during the latter years of child development become more difficult as the child's environment changes and becomes more complex (Foster, Brennan, Biglan, Wang, \& Al-Ghaith, 2002; De Mers, Tincani, Van Norman, \& Higgins, 2009).

This current study sought to add evidence on the importance of using musical engagement as an effective intervention by examining the effects of group musical activities on challenging behaviours. This study also aims to fill the research gap on mixed-method studies relating group musical activities and behaviour-challenged school children in the Philippines. Moreover, this study intends to support the music education paradigm of musical engagement as a social activity and its impact to the development of children using enjoyable experiences with music (Bowman, 2002; Burnard \& Younker, 2010; Elliot, 1995; Hallam, 2010; Kaplan, 1990; Merriam, 1964). The study is premised upon the assumption that music has non-musical outcomes such as behaviour as discussed by Hallam (2010).

\section{Method}

\section{Design and Instrumentation}

This research used a mixed-method case study with a one group pre-posttest design (Riebehl, 2001; Saunders, 2005; Abanes, 2010; Cozby \& Bates, 2012; Yin, 2013; 
Creswell, 2014). Group musical activities served as intervention for the case study participants who were identified to have demonstrated challenging behaviours in school. Qualitative data were gathered through observations, interview, and written outputs during and after the group musical activities. Quantitative data were gathered using the BarOn Emotional Quotient Inventory: Youth Version (BarOn EQ-i: YV), a published instrument for measuring the emotional-social intelligence of children and adolescents, as a pretest and posttest tool (Bar-On, 2000; Bar-On \& Parker, 2000). The instrument consists of seven socio-emotional scales namely: (a) Intrapersonal; (b) Interpersonal; (c) Stress Management; (d) Adaptability; (e) General Mood; (f) Total EQ; and (g) Positive Impression. The reliability of the instrument has an average of $\alpha=.84$ that ranged from low .65 (Interpersonal scale) to high .90 (Total EQ, Stress Management, and General Mood) internal scale consistency (as cited in Killgore \& Yurgelun-Todd, 2007). It has a satisfactory internal reliability of different scales (e.g. $\alpha=.84$ for the Intrapersonal scale and $\alpha=.89$ for the total test) (as cited in Bermejo, Prieto, Fernández, Soto, \& Sainz, 2013).

\section{Participants}

The participants were selected through purposive sampling (Creswell, 2012). The school guidance counsellor identified ten Grade Five students whose challenging behaviours in school necessitated parent-teacher conferences for behaviour processing, monitoring, and guidance. (The term 'challenging behaviours' in this study refers to the negative behaviours which in order to be addressed needed the collaboration of the student, teacher, guidance counsellor, and parents.) Letters with details on the purpose and methods of the study were sent to the parents to request their students' participation. Out of the ten students invited, six were allowed to participate in the study.

Table 1 shows the general profile of the participants including their age, grade level and family set-up. Each participant was assigned a code name. These profiles provided an initial context in understanding (1) the socio-emotional characteristics and behaviours of the students in relation to their age and (2) the relationships and interactions of the students with their family members. 
Table 1

General profile and home set-up of the students

\begin{tabular}{ccccl}
\hline $\begin{array}{c}\text { Case } \\
\text { Study }\end{array}$ & Sex & Age & $\begin{array}{c}\text { Grade } \\
\text { Level }\end{array}$ & Immediate Family Set-up \\
\hline Cleo & Female 11.9 & Grade 5 & $\begin{array}{l}\text { Father and Mother } \\
\text { 1 younger brother } \\
\text { 1 younger sister }\end{array}$ \\
\hline Roger & Male & 11.2 & Grade 5 & $\begin{array}{l}\text { Father } \\
\text { 1 older brother } \\
\text { (Mother is an Overseas Filipino Worker) }\end{array}$ \\
\hline Kaloy & Male & 11.6 & Grade 5 & $\begin{array}{l}\text { Father and Mother } \\
\text { 1 younger brother }\end{array}$ \\
\hline Yan & Male & 11.2 & Grade 5 & $\begin{array}{l}\text { Father and Mother } \\
\text { 3 younger sisters } \\
\text { (older sister already has a family and is not staying } \\
\text { with Yan at home) }\end{array}$ \\
\hline Charo & Female 11.8 & Grade 5 & $\begin{array}{l}\text { Father and Mother } \\
\text { (no siblings) }\end{array}$ \\
\hline $\begin{array}{l}\text { Stepfather and Mother } \\
\text { (biological father is not staying with Charo at home) }\end{array}$ \\
\hline
\end{tabular}

\section{Procedure}

Prior to the administration of group musical activities as intervention, a preintervention phase was done to provide a deeper understanding of the students' behaviour in the context of their musical activities at home and in their music classes. At this stage, data were gathered from the (1) students' portfolio in their music classes (observations, archival records, and creative outputs); (2) interviews with the parents, teachers, guidance counsellor, and case study participants; and (3) responses to a questionnaire used to profile and design plans for the music sessions. The behaviour descriptions primarily stemmed from the guidance report but were validated through parent-teacher conferences and interviews with the students. The data were coded using the techniques presented by Ryan and Bernard (2003).

As a result of the coding process per group, the following challenging behaviours of the students were identified: (1) being insensitive to others; (2) being easily angered; (3) being overly sensitive; (4) having annoying behaviours; and (5) having the tendency to hurt others verbally or get into physical fights. In addition, the coding process showed unique characteristics for each case which included (1) Cleo being competitive; (2) Roger being overly talkative and playful; (3) Kaloy being passive even when he is hurt by his classmates and showing lack of confidence or assertiveness; (4) Yan being overly sensitive and showing lack of assertiveness; (5) Santi being disobedient; and (6) Charo being argumentative and 
pessimistic towards people and situations. Table 2 below summarises the challenging behaviours of the participants.

Table 2

Summary of challenging behaviours

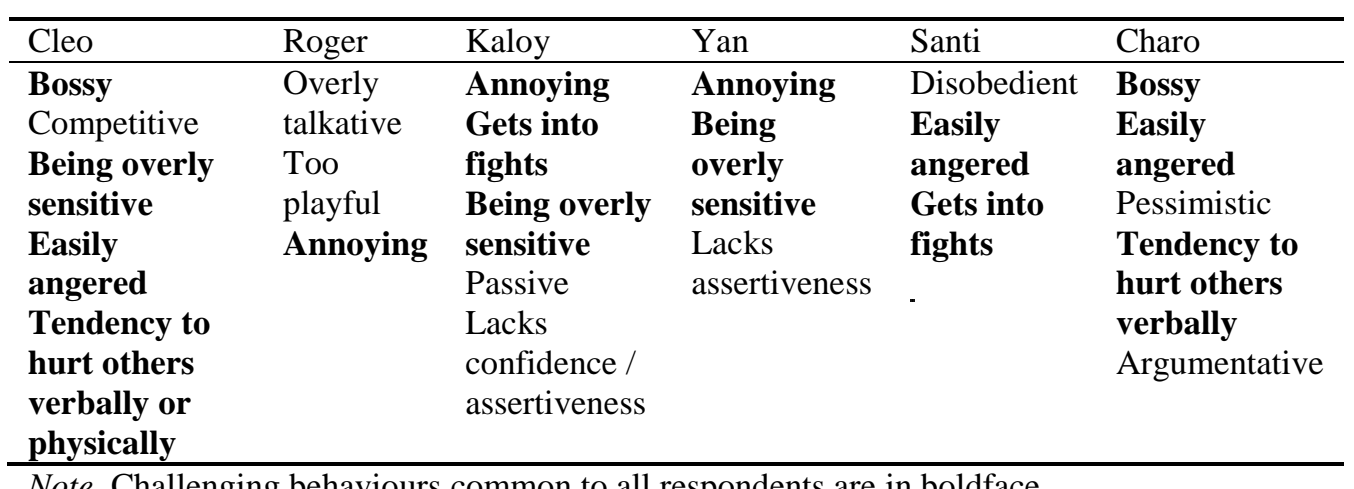

Note. Challenging behaviours common to all respondents are in boldface.

After administering the pretest, the intervention was done through group musical activities or music sessions. The students met twice a week within their school day for a 30-minute music session. During the group musical activities, observations on the students' behaviour, interaction, and performance of the musical activities were recorded through field notes and video recording. Table 3 shows the summary of group musical activities. At the end of the intervention, interviews with the students and their parents were conducted to see if there were changes in the students' behaviour as a result of their participation in the group musical activities. The students were also asked for their feedback and personal assessment of their behaviours and experiences in relation to the musical activities. The BarOn EQ- $i$ : $Y V$ was then employed for posttest. 
Table 3

Summary of musical activities

\begin{tabular}{|c|c|}
\hline \multicolumn{2}{|c|}{ Group Musical Activities (30-minute music sessions) } \\
\hline I. Preparation: & 1. Breathing Exercise \\
\hline $\begin{array}{l}\text { Relaxation and } \\
\text { Focusing }\end{array}$ & 2. Vocal Warm-Up \\
\hline II. Group Musical & Activity 1: Singing 'Music Touches Children Most of All': A \\
\hline Activities & Simple Family Musical (Scene) (Duration: 4 Meetings) \\
\hline \multicolumn{2}{|l|}{ Listening and Moving to } \\
\hline Music & $\begin{array}{l}\text { Activity 2: Combining Singing, Playing, and Improvising } \\
\text { 'Day-O' (Duration: } 2 \text { Meetings) }\end{array}$ \\
\hline \multicolumn{2}{|r|}{ 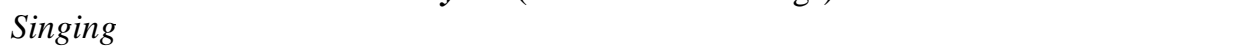 } \\
\hline \multirow{2}{*}{$\begin{array}{l}\text { Playing of instruments } \\
\text { and other sound sources }\end{array}$} & $\begin{array}{l}\text { Activity 3: Combining Marching, Playing, and Singing } \\
\text { 'When the Saints Go Marchin' In' (Duration: } 1 \text { Meeting) }\end{array}$ \\
\hline & Activity 4: Composing a 'A Friend Song' (Duration: 1 \\
\hline \multirow[t]{3}{*}{ Improvising Composing } & Meeting) \\
\hline & $\begin{array}{l}\text { Activity 5: Singing 'Ako'y Isang Pinoy' ('I Am A Filipino') } \\
\text { (Duration: } 1 \text { Meeting) }\end{array}$ \\
\hline & Activity 6: Improvisation Exercise (Duration: 1 Meeting) \\
\hline
\end{tabular}

\section{Description of the Musical Activities}

The 30-minute musical activities that were done twice a week consisted of listening and moving to music, singing, playing of instruments and other sound sources, improvising, and composing. The activities were framed around the musical problem-solving approach with the teacher as a facilitator, scaffolding as the students process ideas or make decisions in and for their music-making (Wiggins, 2001). Problem-solving and its uses in socio-emotional learning in music have been documented by Adamek, Darrow, and Jellison (2013), Atkinson (2015), and Jacobi (2012). The planned music sessions were also guided by the ideas of Merriam (1964), Kaplan (1990), Elliot (1995), Bowman (2002), Burnard and Younker (2010), Hallam (2010) and to keep the group musical experience enjoyable and to achieve goal of socio-emotional development. The activities started with a preparation routine of breathing exercises and vocal warm-up. Then the group musical activities were presented as a musical challenge through role-taking, setting of parameters in addition to the lesson goals, and division of labor (Rief, 2005; Burnard \& Younker, 2010). In every activity, the students were encouraged to describe their experience in making music and to give positive feedback about themselves and others for self-regulation and motivation (McPherson \& Zimmerman, 2002; Maehr, Pintrich, \& Linnenbrink, 2002). 
The first activity, Singing 'Music Touches Children Most of All': A Simple Family Musical (Scene), was a combination of singing and acting for the purpose of forming bonds with peers and enhancing positive interactions (Lau, 2008; Abeles \& Cordero, 2010). The musical challenge was to perform the song as if in a scene from a hypothetical musicale entitled A Simple Family Musical. The students had to conceptualise a particular scene, assign character roles along with their song parts, and perform with simple blockings or actions. They were asked to invite other classmates to serve as audience after they practiced.

The second activity, Combining Singing, Playing, and Improvising 'Day$O$,' had the students take turns being the 'leader' and 'follower' for the call-andresponse parts the song. The musical challenge was for the leader to sing the 'call' part and improvise on the tune on the second round. The role for the rest of the group as followers was to sing the 'response' while playing their selected percussion. After the activity, they described each other's improvisation of the tune and their experience making music. This activity was geared towards developing confidence, creativity, and teamwork especially through singing, instrumentplaying, and improvisation (Greher, Hillier, \& Poto (2010); Gooding, 2011).

The third activity, Combining Marching, Playing, and Singing 'When the Saints Go Marchin' In,' allowed the group to take turns being the 'leader' and 'follower' to encourage their focus and cooperation (Moore, 2002; Kirschner \& Tomasello, 2010). The challenge for the 'leader' was to assign instruments for the group and lead the band in marching. The challenge for the 'followers' was to play the instrument assigned to them while moving. The students were asked to share their thoughts about each other as leaders and about the decisions they made when they were asked to lead.

The fourth activity, Composing 'A Friend Song', had each student become a composer because the musical challenge was to describe a good friend and then create an original tune to his or her descriptions. This activity aimed to open opportunities for sharing and accepting ideas and working together towards a goal (Davoli, 2008; Cross, Laurence, \& Rabinowitch, 2011). They were advised to rehearse their original tunes until it sounded stable to them. Their answers were then connected to comprise a one-stanza song. The group practiced singing the different melodies made. They were asked to play instruments to accompany their singing. Afterwards, they were also asked to share about their ideas for the song and to give their opinions regarding the importance of their individual contribution to the whole group's output.

For the fifth activity, Singing 'Ako'y Isang Pinoy' ('I Am A Filipino'), the musical challenge was to sing in unison and according to their assigned parts, similar to popular singing groups like One Direction. The purpose of this activity was for the students to reflect on their sense of self and national identity as they practice and perform together with excellence (Anshel \& Kipper, 1988; Bowman, 2002; Gardiner, 2000; Abeles \& Custodero, 2010).

The sixth and last activity, Improvisation Exercise, challenged the students to think of positive things about each other based on their musical experiences together and improvise a tune to it as they share their feedback. This activity was designed to give an opportunity for each one to be creative, to express appreciation, 
and to feel accepted (Majoribanks and Mboya, 2004; Cohen, Laya, Sangiorgio, \& Iadeluca, 2011; Gooding, 2011).

\section{Analysis}

Qualitative data were analysed using content analysis for themes (Ryan \& Bernard, 2003). The themes were culled from the related literature (Bar-On, 2000; Schnitzlein, 2006). In order to control researcher bias, the thematic content analysis was validated by the research adviser while the reliability of the data response was confirmed through the triangulation of interviews, observations, and student written outputs. An external music teacher validated the observation results of the group musical activities through the music session videos. A questionnaire was given to the external music teacher as guide in validating noted observations. The validation process from the adviser and external music teacher confirmed the results of the qualitative analysis as acceptable and sound.

The quantitative results from the BarOn EQ-i: $Y V$ test were analysed through a paired sample t-test with a 0.05 level of confidence. A comparison of pretest and posttest raw scores was also employed in the analysis because the nature of the data takes into account individual differences of 'human attributes, ability, personality, motivation, and mood' (Kline, 2000).

\section{Results and Discussion}

\section{Qualitative Data}

Qualitative results from the thematic content analysis of observations, interviews, and written outputs showed that there were changes in the behaviour of the children in terms of (1) being considerate of others' feelings, thoughts, and ideas; (2) doing one's best in a role or task given; (3) being focused; and (4) being creative and confident. These themes summarised the behavioural changes that the students demonstrated during and after the intervention. Table 4 shows who among the students demonstrated the specific change in behaviour. Moreover, upon analysis of the qualitative findings and how they relate to the literature supporting this study, it was found that the encompassing themes which influenced students' positive behaviours during the group musical activities relate to (1) enjoyment and togetherness (Hallam, 2010) and (2) principles on musical engagement and its social context (Merriam, 1964; Kaplan, 1990; Elliot, 1995; Bowman, 2002; Burnard \& Younker, 2010; Hallam, 2010). The discussion of these findings is detailed in the paragraphs that follow. 
Table 4

Students and their Demonstrated Behavioural Change

\begin{tabular}{lcccccc}
\hline Behavioural Changes & Cleo & Roger & Kaloy & Yan & Santi & Charo \\
\hline (1) Being considerate of others & $\checkmark$ & $\checkmark$ & $\checkmark$ & $\checkmark$ & $\checkmark$ & $\checkmark$ \\
(2) Doing one's best in a role or & $\checkmark$ & $\checkmark$ & & $\checkmark$ & & $\checkmark$ \\
task given & & $\checkmark$ & & $\checkmark$ & $\checkmark$ & \\
(3) Being focused & & $\checkmark$ & & $\checkmark$ & $\checkmark$ & $\checkmark$ \\
(4) Being creative and confident & $\checkmark$ & $\checkmark$ & & $\checkmark$ \\
\hline
\end{tabular}

Findings on students and their improved behaviours. Aside from these four changes, analysis of the students' behaviour as documented from the observations, interviews, and written evaluation, revealed more specific improvements. These improvements are summarised for each student below.

Cleo. Patience was one of the most observable behaviour of Cloe during and after the intervention. This was manifested in her effort to listen to her groupmates ideas and suggestions without reprimanding them even when they started making jokes or became overly playful. When teased, she expressed disagreement but simply laughed about it with the other person. At home, her father remarked that Cleo has shown patience by managing her temper and emotions. Her adviser and guidance counsellor also noted her improvement on controlling her anger. Even Cleo mentioned that she was able to better deal with others and establish friendships during the musical activities. In her written evaluation, she shared about seeing the 'good and bad qualities' of her groupmates as she participated in the sessions. According to her, one of things she needed to improve on was on being careful with words ('I should also watch the words coming out of my mouth').

Roger. In all the activities, Roger actively participated and showed enjoyment with the group. His enjoyment was sometimes accompanied by making funny remarks especially when the boys in the group joked around, too. However, an immediate reminder to practice self-control was enough for him to focus back on the musical activity. In an interview with Roger's grandmother, she shared that although Roger still needed to be reminded, he improved on following instructions and lessened the tendency to complain and talk back. The guidance counsellor and his advisor also observed Roger's need for reminders; but they observed that he had minimised provoking people through teasing. His adviser said that it was no longer Roger who would start a bad joke. According to Roger, the group musical activities helped him discover his capabilities that improved his confidence. Aside from that, he said his tendency to be very talkative and annoying to others was minimised because he intended to focus on the task. In Roger's written evaluation, he wrote that being able to improvise 'Tagalog lyrics' (Tagalog is one of the languages in the Philippines) may have helped him improve his behaviour.

Kaloy. Kaloy actively involved himself in working with the group to solve a musical challenge like in the Simple Family Musical. He expressed his unique ideas 
and suggestions freely, which was welcomed by the group. However, there was still a time when his remarks annoyed and distracted some of his groupmates. Kaloy calmed himself when it was already singing time. The group, with the researcher, processed the situation after the performance in the context of how 'bandmates' should adjust to one another despite differences and misunderstandings. In his interview, he mentioned that the role-playing task in the Simple Family Musical helped him understand his groupmates. According to him, being able to understand others minimised his tendency to annoy or making teasing remarks. In the written output, he recognised that teasing others was part of his funny nature but realised that it was one thing he has to improve on. This ability to monitor himself was observed by the guidance counsellor and his advisor. They noted that he continued to blurt out ideas and jokes but he was not into fights. In addition, Kaloy's mother said that the group musical activities were helpful to her son's behaviour despite being absent for the majority of the sessions. She agreed that Kaloy may have benefitted from the musical activities in developing good behaviours and in dealing with challenging ones.

Yan. During one of the sessions when he became sensitive over Kaloy and Santi's joke about him, Yan was able to show a degree of resilience by not quitting the activity, leaving the group, or sulking. Despite his weakness in handling jokes and negative remarks, he performed his best by singing his parts confidently and putting up with the activity and with his groupmates until the end. Singing was one of the activities where he exhibited much focus, talent, and confidence. He made creative variations to melodies used in some songs. His father mentioned that the group musical activities supported his son's passion for music and singing, which in turn seemed to have affected how Yan dealt with his siblings and his classmates. He had observed that Yan refrained from hurting his siblings despite feeling angry. Moreover, the school guidance counsellor observed that Yan has better emotional awareness and shows ability 'to empower himself' or boost his self-regard. This self-awareness was also evident in Yan's assessment of himself. Yan remarked in his interview that the group musical activities were helpful in making himself better ('a good person recently') although he indicated that he needed to improve on being more energetic. Through the activities, he said he discovered good things about himself that made him feel contented like his voice type (' $I$ am an alto singer even[though] I am a boy. I am happy with the voice that was given to me by The God'). Being more confident was an aspect he said he was able to improve on. He also mentioned that somehow, in a session when he was teased by some groupmates, he managed to be steadfast and was able to control his emotions. The musical sessions for him became a time when he found his schoolmates really kind and playful.

Santi. Despite of being remarked as disobedient, Santi during the group musical activities, was able to follow the leader, carry out his role in the group, relate with others, and perform his assigned roles as a singer or instrumentalist. There were times when he needed some prompting in order to follow, like during the breathing exercises and vocal warm-ups; but he participated in every process of 
the musical activities and did his best in complying though he preferred playing the beat box. Like Kaloy, singing his assigned part calmed him down from laughing around during the activities. Santi's mother mentioned in an interview that she saw the group musical activities beneficial for Santi in helping him with his challenging behaviours. She expressed that her son shared about the activities (e.g. his role in the Simple Family Musical) and that he looked forward to the music sessions. She believes that the group musical activities gave Santi a sense of belongingness (e.g. an instance when her son still wanted to make friends even after his teasing and joking went too far). For her, being more empathic was an area Santi needed to improve on. In terms of following instructions, she mentioned that Santi would comply but reminders and explanations were still necessary because he had the tendency to get distracted by many things. The guidance counsellor and adviser also mentioned about Santi's need for reminders but is was observable that he no longer provoked fights. These changes were also recognised by Santi as he noted that being patient and kind to people were his good behaviours during the group musical activities ('I know how to be patient and kind to people'). When asked to explain how the musical activities were helpful to him, he mentioned about teamwork where he had to work with others in singing and composing songs. He believed that working together was fun and good for establishing friendships. As a realisation, he mentioned in his written output that he needed to develop 'being loving to people'.

Charo. Charo showed self-control in dealing with groupmates who were difficult to work with. When the boys did not follow or pay attention immediately, she reacted in her usual strict attitude by reprimanding them. However, it was not in a hurtful way like before. During the planning of a performance, she considered others' suggestions and enjoyed trying them out. Even though she has Attention Deficit Hyperactivity Disorder (ADHD), Charo was able to control herself and manage to focus on the musical activities with others. Like Cleo, Charo exerted her best effort during the group activities. She followed instructions carefully and concentrated on the tasks, much more when she was assigned the singing parts. Although she was shy when it came to singing alone, Charo did her best in trying to be confident, even with a small voice. In an interview with Charo's mother, she said that her daughter showed better self-control even if she was still being overly active. Dealing with others and being more confident were the other areas Charo seemed to improve on. The guidance counsellor and adviser also had a similar remark with the way she socialised and dealt with others. The group musical activities may have helped Charo's behaviours in a way according to Charo's mother, even if she missed other sessions. Possible reasons for not attending the activities, except the Simple Family Musical and the last meeting, were Charo's preference for other activities like outdoor play or being with other friends. In an interview with Charo, she said the group musical activities helped her slightly. She expressed that the musical activities helped improve her creativity and ability to relate with difficult people. An example she cited was in controlling her anger when her groupmates failed to understand or follow immediately. In her written output, she perceived that being joyful, being a good listener, and being able to improvise music were her 
good behaviours in the group activities. However, she noted that she needed to be more patient and 'open-minded.'

Findings on the musical challenges and behaviour. The socialisation process during the musical activities became another factor for the students to practice self-regulation processes for musical learning (McPherson \& Zimmerman, 2002). Reinforcements, guidance, social structuring, and help given by others facilitated motivation and monitoring, as well as the students' effort to adjust their way of learning, performing, and behaving (Maehr, Pintrich, \& Linnenbrink, 2002).

The musical challenge is linked with the social component of solving problems together which involves negotiations and interactions among the participants of the group. This is supported by Elliot's (1995) ideas on how music and music-making operates in a social context and how creative and criticalthinking skills are involved and developed in problem-solving settings for musical understanding (Wiggins, 2001). The discussion that follows was organised according to musical activity and the musical challenge.

Singing with assigned roles and parts. The challenges in the Simple Family Musical were in the task of singing in unison and with assigned parts and in planning and rehearsing together given a short time. The family roles they came up with had an effect in the way they regarded each other during the succeeding sessions. This jumpstarted the group to get more comfortable with each other because the particular role they played in this 'family musical' allowed them to form bonds with peers (Abeles \& Custodero, 2010) by way of paying attention to the one singing, waiting patiently for their turn, and making sure they sound together with their partners or in unison. Majoribanks and Mboya (2004) support this idea of music being a safe place to express oneself and be accepted by others. Moreover, in a study about singing games to enhance social skills by Lau (2008), these positive behaviours that relate to confidence, establishing and maintaining positive interactions and relationships, and enjoying and accepting each other were seen in the findings.

In another singing activity, a conflict emerged among the boys. The musical challenge of being assigned a singing part may have challenged the students' sense of security and in being identified with the group (Bowman, 2002; Abeles \& Custodero, 2010). However, embodying a singing 'boy band' (since only the boys were present), Kaloy, Roger, Santi, and Yan still became responsible and confident with their assigned parts. The activity paved a way for the boys to assess themselves by answering processing questions on how to relate with 'bandmates' who have different personalities but are equally important in the 'boy band.' The musical activity may have alleviated the tension that could trigger uncontrolled anger and fighting (Choi et al., 2008) and built their self-esteem when they sang their parts correctly (Gardiner, 2000).

Combined moving to music, instrument-playing, singing and taking turns in leading and following. Aside from making music, the students enjoyed being the leader assigning roles (instrumentalist, singer, or movement in-charge) and being given different roles. The 'followers' paid attention and followed the decisions of 
the 'leader.' There were negotiations but every turn ended with a unified performance. Moore's (2002) study supported the idea of including varied movements to songs to increase attentiveness on on-task behaviours. While the amount of engagement in the song increased, off-task behaviour decreased.

Confidence and teamwork as instrumentalists. The instrumentalist role appealed to the participants and observably became the favoured option between being assigned a singing or improvisation role like for Cleo and Santi. But when asked to perform on the spot, there were hesitations. In the group, Santi showed confidence when playing the beat box for the group. Hallam and Prince (2000) revealed in their study that playing instruments were found beneficial to students in the development of enjoyment of music, a sense of accomplishment, confidence, and self-discipline.

In addition, as the group played percussion instruments, they listened to each other and considered the kind of playing or rhythms necessary. They made rhythmic patterns, complimented one other's beats, and controlled the dynamics or volume level of their playing. To sound harmonious, the group achieved teamwork when they made music through instruments and other sound sources (Hallam and Prince, 2000).

Original contributions in improvising and composing. The freedom experienced by the group through song improvisations can be credited to Roger's initial contributions to this kind of activity in an effortless way. Since he was a natural in improvising tunes, he was able to start the activity that prompted the others to overcome shyness and try improvising. The group enjoyed recalling each other's version of the same lyrics. Similar to the experience of advanced musical ensembles, the students' initial participation was very much likely influenced first by the positive feedback they received from others, and their continued participation was because of the positive experiences they had with both the music and with others (Hewitt and Alan, 2012).

Additionally, in the composition activity, the students helped each other in weaving the sentences into a song and they were allowed to vary some parts if they could not remember the initial tune. Listening to and singing the ideas they associate with friendship became a 'comfort factor' for the group (Hoffer, 2002) and enabled them to understand what others consider to be a good friend (Cross et al., 2011).

Findings on the enjoyment and togetherness in the musical challenge. The students' engagement and enjoyment enabled their harmonious interactions with one another towards a goal. According to Hallam (2010), the primary consideration for musical engagement to have an impact on the personal and social development of children is that the experience should be enjoyable and rewarding. The students' active involvement in the group musical activities provides evidence of their enjoyment. In addition, the students' tendency to make jokes and invite laughter during their group conversations also add evidence on how much the students enjoyed doing their tasks which resulted in a successful musical output like a composed song or a performance. 
Aside from a successful musical output, the enjoyment experienced and the lessons learned by the students as they fulfilled their roles in the group were heightened when they succeeded together despite difficulties in meeting the challenges and in working with others. The children experienced different ways of considering other people's ideas, interests, and feelings in the group musical activities. Riedel (1964), cited by Paul and Ballantine (2002) supports the idea of 'sociability' of music in giving a 'feeling of belonging to a group' and the 'feeling of togetherness through the performance of music.' The musical activity or task with peers necessitated the communication and role-playing for a successful performance (Burnard \& Younker, 2010). The students positively took their roles and learned from this. Cleo and Charo, for instance, learned how to improve their way of dealing with challenging groupmates. Roger, Kaloy, Yan, and Santi learned how to follow rules and cooperate with other people. Concerning Charo's ADHD, the group musical activities involved her in 'cooperative learning' by practicing 'interdependence,' 'individual accountability,' and social skills beneficial to students with such condition (Johnson, Johnson, and Holubec, 1998, cited by Rief, 2005).

What resulted from the group musical experiences of the students in musicmaking and working with others also validated a study by Cross, Laurence, and Rabinowitch (2011) which showed that empathy and creativity are developed in 'group musical practices.' The emphatic processes at work in a 'collaborative creative musical activity' directed the children to consider the thoughts and feelings of others. Laurence (2010) also reiterated this emphatic process at play when children are 'musicking' (music-making in the context of relationships with the music and the people making the music) and where this can lead to 'further musicking.' Also, as the students engage in developing musicianship and valuing of others, they also develop their self-esteem (John, 2004). According to John (2004), 'active musicianship' through 'music-making and music listening' and the affective or emotional dimension of students should go together and must be developed in "social contexts."

The effects seen in the case study participants in the area of improving social competence and personal development relate to the results of the music intervention program called Music is Fun by Schnitzlein (2006). In her study, positive results were seen in the character traits of the students in terms of the following: 'focus and concentration,' 'participation and cooperation,' and 'confidence and courage.'

\section{Quantitative Data}

Quantitative findings from the two-tailed paired t-test of the group's BarOn EQ-i: $Y V$ results were not significant (see Table 5). However, the differences in the pretest and posttest raw scores varied per student (see Tables 6-10). 
Table 5

Summary of BarOn EQ-i: YV T-test Result

\begin{tabular}{llll}
\hline BarOn EQ-i: $\boldsymbol{Y} \boldsymbol{V}$ Scales & $\begin{array}{l}\text { Pretest and Posttest } \\
\text { T-Test Results }\end{array}$ & $\begin{array}{l}\text { P-Value } \\
\text { (two-tailed) }\end{array}$ & Remarks \\
\hline Intrapersonal & -2.011 & 0.101 & Not significant \\
Interpersonal & -0.264 & 0.802 & Not significant \\
Stress Management & -0.036 & 0.973 & Not significant \\
Adaptability & -0.271 & 0.797 & Not significant \\
Total EQ & -0.586 & 0.583 & Not significant \\
General Mood Scale & 0.257 & 0.087 & Not significant \\
Positive Impression & -1.874 & 0.120 & Not significant \\
\hline
\end{tabular}

Table 6

Intrapersonal scale results

\begin{tabular}{lcccc}
\hline & \multicolumn{2}{c}{ Pretest Result } & \multicolumn{2}{c}{ Posttest Result } \\
\cline { 2 - 5 } Participants & Raw Score & Interpretation & Raw Score & Interpretation \\
\hline Cleo & 15 & Average & 15 & Average \\
Roger & 14 & Average & 16 & Average \\
Kaloy & 12 & Average & 15 & Average \\
Yan & 14 & Average & 15 & Average \\
Santi & 9 & Very Low & 16 & Average \\
Charo & 20 & Very High & 20 & Very High \\
\hline
\end{tabular}

Table 7

Interpersonal scale results

\begin{tabular}{lcccc}
\hline & \multicolumn{2}{c}{ Pretest Result } & \multicolumn{2}{c}{ Posttest Result } \\
\cline { 2 - 5 } Participants & Raw Score & Interpretation & Raw Score & Interpretation \\
\hline Cleo & 39 & Average & 38 & Average \\
Roger & 35 & Low & 26 & Markedly Low \\
Kaloy & 38 & Average & 29 & Very Low \\
Yan & 32 & Low & 39 & Average \\
Santi & 33 & Low & 39 & Average \\
Charo & 38 & Average & 39 & Average \\
\hline
\end{tabular}


Table 8

Stress management scale results

\begin{tabular}{lcccc}
\hline & \multicolumn{2}{c}{ Pretest Result } & \multicolumn{2}{c}{ Posttest Result } \\
\cline { 2 - 5 } Participants & Raw Score & Interpretation & Raw Score & Interpretation \\
\hline Cleo & 22 & Very Low & 24 & Very Low \\
Roger & 35 & Average & 30 & Average \\
Kaloy & 33 & Average & 35 & Average \\
Yan & 19 & Markedly Low & 28 & Low \\
Santi & 36 & Average & 31 & Average \\
Charo & 29 & Low & 27 & Low \\
\hline
\end{tabular}

Table 9

Adaptability scale results

\begin{tabular}{lcccc}
\hline & \multicolumn{2}{c}{ Pretest Result } & \multicolumn{2}{c}{ Posttest Result } \\
\cline { 2 - 5 } Participants & Raw Score & Interpretation & Raw Score & Interpretation \\
\hline Cleo & 30 & Average & 35 & High \\
Roger & 27 & Average & 26 & Average \\
Kaloy & 31 & Average & 22 & Very Low \\
Yan & 28 & Average & 24 & Low \\
Santi & 24 & Low & 35 & High \\
Charo & 34 & High & 36 & High \\
\hline
\end{tabular}

Table 10

Total EQ scale results

\begin{tabular}{lcccc}
\hline & \multicolumn{2}{c}{ Pretest Result } & \multicolumn{2}{c}{ Posttest Result } \\
\cline { 2 - 5 } Participants & Raw Score & Interpretation & Raw Score & Interpretation \\
\hline Cleo & 53 & Average & 56 & Average \\
Roger & 54 & Average & 50 & Low \\
Kaloy & 56 & Average & 50 & Low \\
Yan & 47 & Low & 53 & Average \\
Santi & 49 & Low & 57 & Average \\
Charo & 62 & Average & 63 & High \\
\hline
\end{tabular}

In this study, possible threats to validity of the quantitative data that were identified by Cozby and Bates (2012) and Cohen, Manion, and Morrison (2013) and were present-history and experimental mortality. Since the treatment and test schedules were done during a part of the students' lunch time, changes (cancellation of classes, sickness, or personal choice) took place during the course of the musical intervention affecting the regularity of set conditions (time, place, and group 
attendance). These factors could have affected the results for Kaloy (sickness) and Charo (choice) resulting in the possibility for variance of the group result. Other factors affecting the results may have been the time interval between the PreIntervention and Post-Intervention tests.

While some of the qualitative and quantitative findings complement each other, other results were found to be contradictory. The possible factors for these discrepancies may be the following: 1) Reliability of the BarOn EQ-i: $Y V$ instrument; 2) Language of the test; 3) Schedule of the treatment and the test-taking; 4) Failure to complete the treatment sessions; and 5) Limited time frame for the treatment. A study done by Al Said, Birdsey, and Stuart- Hamilton (2013) among Omani children recommended standardizing the instrument for that particular population. This could be the case for Roger who was consistently present and involved in the group musical activities. His results showed a decrease, except in the Intrapersonal scale, which did not coincide with the qualitative findings. Although Said et al. (2013) used the shorter version of the BarOn Youth Version inventory to make it suitable for their population, the recommendation by the authors is worth noting because it was pointed out that one of the limitations of the BarOn EQ-i: YV could be its heavy reliance on language comprehension. The test might not be appropriate for students with language and reading problems (2013) and need to be standardized for the Filipino norm. In Roger's case, having a difficulty in English, language could have been a factor affecting the results.

However, considering the pretest and posttest raw scores, some of the quantitative results supported qualitative findings particularly that of Cleo, Santi, and Yan's Total EQ result; Cleo and Santi's Adaptability result; Yan's Stress Management result; and Santi's Intrapersonal result.

\section{Conclusion and Recommendations}

The study found that group musical activities could help improve children's behaviour to a certain extent as the qualitative and quantitative results are mixed. As the children faced musical challenges together, positive behaviours were practiced in their musical and social interactions. The students revealed changes in their behaviour in terms of self-esteem, understanding others, managing emotions, cooperation, being focused, and doing one's best. One of the significance of this study is to build on Hallam's (2010) idea to make the musical experiences enjoyable to benefit children having difficulties in dealing with negative behaviours. Parents, teachers, and guidance counsellors can also gain from the study through added knowledge and understanding of the value and function of music in the children's lives, particularly on music-making activities with others. Music educators can consider applying problem-solving approaches in the music classroom to build the students' socio-emotional skills and partner with the school in giving music intervention to those with challenging behaviours. In terms of protocol, the use of the BarOn EQ-i: $Y V$ in music intervention may be used to monitor socio-emotional behaviour. However, this study suggests further reliability testing of the instrument 
for the Filipino population to strengthen the instrument's applicability for the Filipino children and adolescents

The study recommends curriculum-makers and music educators to prioritise group musical activities as an integral part of the music curriculum in school because it can serve as a means of intervention for regular school children. Music educators also need to consider shifting the focus from the music and performance to their students through a transformative music pedagogy (Cameron \& Carlise, 2004). Future research should venture into making longitudinal studies of group musical activities in improving socio-emotional behaviours or other mixed-method studies such as mixed-method ethnography or narrative research and embedded experimental or correlational designs. Also, new research can focus on a particular social and emotional behaviour like the study about empathy and music-making by Cross, Laurence, and Rabinowitch (2001) for a deeper understanding of how music can help improve children's behaviour. In terms of employing quantitative measures, the study recommends that the following factors be considered: the sample size in relation to the type of study or statistical analysis, increasing the number or duration of musical sessions, conducting a similar study in a music class setting, and establishing observation checklists and norms. There are still more opportunities for research in the area of music and children's behaviour and character development, especially in the Philippines. This study hopes to encourage researchers to add more to this field and for music educators to continue in their pursuit to help in the holistic development of students through music.

\section{References}

Abanes, K. (2010). Parenting, custodial arrangement, and socio-emotional adjustment of children of separated parents. Unpublished masters thesis. University of the Philippines: College of Education.

Abeles, H.F. \& Custodero, L.A. (2010). Critical issues in music education: Contemporary theory \& practice. New York, NY: Oxford University Press, Inc.

Adamek, M., Darrow, A., \& Jellison, J. (2013) Music therapy practice and selfdetermination for students with disabilities. Paper presented at the 2013 National In-Service Conference: Hot Topics in Special Music Education, www.nafme.org/wp-content/files/Store/Digital-Products/hot_topics_cart.pdf

Al Said, T.B.T, Birdsey, N., \& Stuart-Hamilton, I. (2013). Psychometric properties of bar-on emotional quotient inventory." International Journal of Learning Management System, 1(2), 13-24. Retrieved from http://www.naturalspublishing.com/files/published/ej337t87282jft.pdf

Aldridge, D. (1993). Music therapy research 1: A review of the medical research literature within a general context of music therapy research. The Arts in Psychotherapy, 20(1), 11-35. Retrieved from mustherapy.narod.ru/mtreview.pdf

Allsup, R. E. \& Westerlund, H. (2012). Methods and situational ethics in music education. Action, Criticism, and Theory for Music Education,11(1), 124-48. Retrieved from http://act.maydaygroup.org/articles/AllsupWesterlund11_1.pdf 
Anshel, A. \& Kipper, D.A. (1988). The influence of group singing on trust and cooperation. Journal of Music Therapy, 25(3), 145-155. Retrieved from westallen.typepad.com/files/anshel-jmustherapy-1988.pdf

Atkinson, P. (2015). Social emotional learning in the music classroom: A cross-case analysis of teacher experiences in the rock and roll academy. Unpublished doctoral dissertation. The University of Alabama: Graduate School

Bar-On, R. (2000). Emotional and social intelligence: Insights from the Emotional Quotient Inventory (EQ-i). In R. Bar-On and J.D.A. Parker (Eds.), Handbook Of Emotional Intelligence: Theory, development, assessment and application at home, school and in the workplace. San Francisco, CA: Jossey-Bass.

Bar-On, R., \& Parker, J.D.A. (2000). The BarOn Emotional Quotient Inventory: Youth Version (EQ-i:YV): Technical manual. Toronto, Canada: Multi-Health Systems.

Bermejo, R., Prieto, M.D., Fernández, M.C., Soto, G., \& Sainz, M. (2013). A cognitivecreative profile of emotional talent. New Approaches in Educational Research, 2(1), 12-16. DOI: 10.7821/naer.2.1.12-16.

Bowman, Wayne. (2002). Educating musically. In Richard Colwell and Carol Richardson (Eds.), The new handbook of research on music teaching (pp. 63-84). New York, NY: Oxford University Press.

Burnard, P. \& Younker, B. (2010). Chapter 11: Towards a broader conception of creativity in the music classroom: A case for using Engestöm's Activity Theory as a basis for researching and characterizing group music-making practices. In R. Wright (Ed.), Sociology and music education (pp. 165-191). Vermont, USA: Ashgate Publishing Company.

Cameron \& Carlise (2004). What kind of social climate do we create in our music classrooms?. In Lee R. Bartel (Ed.), Questioning the music education paradigm (pp. 21-38). Ontario, Canada: Canadian Music Educator's Association.

Choi, A., Lee, S., \& Lee, J. (2008). Group music intervention reduces aggression and improves self-esteem in children with highly aggressive behavior: A pilot controlled trial. Advance Access Publication, 7(2), 213-217. Retrieved from http://dx.doi.org/10.1093/ecam/nem182

Cohen, L., Manion, L., \& Morrison, K. (2013). Research method in education. London: Routledge.

Cohen, M. L., Laya, S. H., Sangiorgio, A., \& Iadeluca, V. (2011). At-risk youth: Musicmaking as a means to promote positive relationships. In G. MacPherson (Ed.), Handbook of Music Education (pp.185-202). New York, NY: Oxford University Press.

Cozby, P. \& Bates, S. (2012). Methods in behavioral research. $11^{\text {th }}$ ed. New York, NY: McGraw-Hill.

Creswell, J. W. (2012). Educational research: Planning, conducting, and evaluating quantitative and qualitative research. $4^{\text {th }}$ ed. Boston, MA: Pearson Education, Inc.

Creswell, J. W. (2014). Research design: qualitative, quantitative, and mixed methods approaches. 4th ed. Thousand Oaks, CA: SAGE Publications.

Cross, I., Laurence, F., \& Rabinowitch, T. (2011). Empathy and creativity in group musical practices: Towards a concept of emphatic creativity. In G. MacPherson (Ed.), Handbook of Music Education (pp.185-202). New York, NY: Oxford University Press.

Davoli, C. (2008). Reaching urban youth exposed to violence through music therapy a literature based study. Unpublished thesis. Retrieved from http://idea.library.drexel.edu/bitstream/1860/2990/1/Carrie\%20Davoli.pdf 
De Mers, C., Tincani, M., Van Norman, R. (2009). Effects of music therapy on young children's challenging behaviors: A case study. Music Therapy Perspectives, 27(2), 88-96. https://doi.org/10.1093/mtp/27.2.88

Elliot, D.J. (1995). Music matters: A new philosophy of music education. New York, NY: Oxford University Press.

Foster, S.L., Brennan, P.; Biglan, A., Wang, L., \& Al-Ghaith, S. (2002). Preventing behaviour problems: What works. In Educational Practices Series 8. Retrieved from http://www.ibe.unesco.org/fileadmin/user_upload/archive/publications/Education alPracticesSeriesPdf/prac08e.pdf

Fox, L., Dunlap, G., \& Powell, D. (2002). Young children with challenging behavior. Journal of Positive Behavior Interventions, 4(4), 208-217. Retrieved from http://journals.sagepub.com/doi/pdf/10.1177/10983007020040040401

Gardiner, M. (2000). Music, learning, and behavior: A case for mental stretching. Journal for Learning Through Music, 1(1). Retrieved from http://music-ineducation.org/articles/1-R.pdf

Gooding, L. F. (2011). The effect of a music therapy social skills training program on improving social competence in children and adolescents with social skills deficits. Journal of Music Therapy, 48(4), 440-462. Retrieved from http://jmt.oxfordjournals.org/content/48/4/440.full.pdf

Greher, G.R., Hillier, A., Dougherty, M., \& Poto, N. (2010). Soundscape: An interdisciplinary music intervention for adolescents and young adults on the autism spectrum. International Journal of Education \& the Arts, 11(9). Retrieved from http://www.ijea.org/v11n9/

Hallam, S. (2010). The power of music: Its impact on the intellectual, social and personal development of children and young people. International Journal of Music Education, 28(3), 269-289. Retrieved from http://ijm. doi: $10.1177 / 0255761410370658$

Hallam, S., \& Prince, V. (2000). Research into instrumental music services. Retrieved from core.kmi.open.ac.uk/download/pdf/4154301.pdf

Hewitt, A. \& Allan, A. (2012). Advanced youth music ensembles: Experiences of, and reasons for, participation. International Journal of Music Education, 31(3), 257275. Retrieved from http://ijm.sagepub.com/content/31/3/257

Hoffer, C. (2002).Music Listening Today. New York, NY: Schirmer.

Jacobi, B. (2012). Opportunities for socioemotional learning in music classrooms. Music Educators Journal, 99(2), 68, 70-74.

John, B. (2004). Chapter 18: Relating music and affect: An alternative model for structuring music instruction. In L.R. Bartel (Ed.), Questioning the Music Education Paradigm Vol. 2 of the Biennial Series, Research to Practice, (pp. 258-269). Canada: Canadian Music Educators' Association.

Kaplan, M. (1990). The arts: A social perspective. Cranbury, NJ: Fairleigh Dickinson University Press.

Killgore, W. \& Yurgelun-Todd, D. (2007). Neural correlates of emotional intelligence in adolescent children. Cognitive, Affective, \& Behavioral Neuroscience, 7(2), 140151.

Retrieved

from http://scholar.google.com.ph/scholar_url?hl=en\&q=http://www.researchgate.net/p ublication/6167714_Neural_correlates_of_emotional_intelligence_in_adolescent_ children/file/9fcfd50ae496aee515.pdf\&sa=X\&scisig=AAGBfm2tPvEFgLBZh_g5VZ88qlgPDtntA\&oi=scholarr\&ei=SYSXU92 yAYz48QXPr4LADw\&ved=0C BsQgAMoADAA 
Kirschner, S. \& Tomasello, M. (2010). Joint music making promotes prosocial behavior in 4-year-old children. Evolution and Human Behavior, 31, 354-364. Retrieved from http://www.eva.mpg.de/psycho/pdf/Publications_2010_PDF/Kirschner_Tomasell o_2010.pdf

Kline, P. (2000). Standardising the test. In The handbook of psychological testing ( ${ }^{\text {nd }}$ Ed.) (Chapter 4). Retrieved from http://books.google.com.ph/books?id=lm2RxaKaok8C\&printsec=frontcover\&sou $\mathrm{rce}=\mathrm{gbs} \_\mathrm{ge} \_$summary_r$\& \mathrm{cad}=0 \# \mathrm{v}=$ onepage $\& \mathrm{q} \& \mathrm{f}=$ false

Lau Wing Chi, M. (2008). Using singing games in music lessons to enhance young children's social skills. Asia-Pacific Journal for Arts Education, 6(2), 1-28. Retrieved from http://www.ied.edu.hk/cca/apjae/Vol\%206\%20No\%202.pdf

Laurence, F. (2010). Chapter 15: Listening to children: voice, agency and ownership in school musicking. In R. Wright (Ed.), Sociology and Music Education (pg. 243262). Vermont, USA: Ashgate Publishing Company.

Lehmann, A.C., Sloboda, J.A., \& Woody, R.H. (2007). Psychology for musicians: Understanding and acquiring the skills. New York, NY: Oxford University Press.

Machalicek, W., O’Reilly, M. F., Beretvas, N., Sigafoos, J., \& Lancioni, G. E. (2007). A review of interventions to reduce challenging behavior in school settings for students with autism spectrum disorders. Research in Autism Spectrum Disorders, 1(3), 229-246. Retrieved from https://www.researchgate.net/profile/Wendy_Machalicek/publication/222818237_ A_review_of_interventions_to_reduce_challenging_behavior_in_school_settings_ for_students_with_autism_spectrum_disorders/links/0deec52afc103e8620000000/ A-review-of-interventions-to-reduce-challenging-behavior-in-school-settings-forstudents-with-autism-spectrum-disorders.pdf

Maehr, M.L., Pintrich, P.R. \& Linnenbrink, E.A. (2002). Motivation and achievement. In R. Colwell and C. Richardson (Eds.), The new handbook of research on music teaching and learning. New York: Oxford University Press.

Majoribanks, K., \& Mboya, M. (2004) Learning environments, goal orientations, and interest in music. Journal of Research in Music Education, 52(2), 155-166.

McPherson, G.E. \& Zimmerman, B.J. (2002). Self-regulation of musical learning: A social cognitive perspective. In R. Colwell and C. Richardson (Eds.), Handbook of research on music teaching and learning. New York, NY: Oxford University Press.

Merriam, A.P. (1964) Chapter 7: Learning. In The anthropology of music. Chicago: Northwestern University Press.

Moore, R. (2002). Influence of multicultural singing games on primary school children's attentiveness and song preferences in music class. International Journal of Music Education, (39)31, 31-39.doi: 10.1177/025576140203900104

North, A., Tarrant, M. \& Hargreaves. D. (2004). The effects of music on helping behavior: A field study. Environment And Behavior, 36(2), 266-275.doi: $10.1177 / 0013916503256263$

Paul, S.J. \& Ballantine, J.H. (2002). The sociology of education and connections to music education research. In R. Colwell (Ed.), Handbook of research on music teaching and learning. New York, NY: Schirmer Books.

Reibehl, D. M. (2001). Co-curricular music lessons improve student behavior: A case study. Action research. Retrieved from www.angelfire.com/band2/pmmack/casestudy

Rief, S.F. (2005). How to reach and teach children with ADD/ADHD: Practical techniques, strategies, and interventions ( $2^{\text {nd }}$ ed.). San Francisco, CA: Jossey-Bass.

Ryan, G. \& Burnard, H. R. (2003). Techniques to identify themes. Field Methods, 15(1), 85- 
109. doi: $10.1177 / 1525822 \mathrm{X} 02239569$

Schnitzlein, B.D. (2006). Developing children's character through music: A case for philosophy of education. Unpublished doctoral dissertation. UP Diliman: College of Education.

Sink, P.E. (2002). Behavioral research on direct music instruction. In R. Colwell (Ed.), Handbook of research on music teaching and learning. New York, NY: Schirmer Books.

Stamou, L. (2002). Plato and Aristotle on music and music education: Lessons from ancient Greece. International Journal of Music Education, 39, 3-16.doi: $10.1177 / 025576140203900102$.

Standley, J. (1996). A meta-analysis on the effects of music as reinforcement for education/therapy objectives. In R. Deasy (Ed.), Critical links: Learning in the arts and student academic and social development (2002). Washington, DC: Arts Education Partnership. Retrieved from http://www.artreachsandiego.org/research/CriticalLinks.pdf

Saunders, J. (2005). The case study as a method for exploring expert music teaching. Brock Education Journal, (15)1, 32-42. http://dx.doi.org/10.26522/brocked.v15i1.62

Whipple, J. (2004). Music in intervention for children and adolescents with autism: A metaanalysis. Journal of Music Therapy, 41 (2), 90-106.doi: 10.1093/jmt/41.2.90

Wiggins, J. (2001). Teaching for musical understanding. New York, NY: McGraw-Hill.

Yin, R. K. (2003). Case study research: Design and methods. Thousand Oaks, CA: Sage Publications.

\section{Biography}

Shiela Jay Pineda is a music instructor for Grades 3 to 6 in the University of the Philippines Integrated School. She graduated with the degree of Master in Music Major in Music Education. 